\title{
Shakespeare's Scattered Leaves: Mutilated Books, Unbound Pages, and the Circulation of the First Folio
}

\section{Christy Desmet}

\section{(2) OpenEdition \\ 12 Journals}

\section{Édition électronique}

URL : http://journals.openedition.org/shakespeare/4785

DOI : $10.4000 /$ shakespeare.4785

ISSN : 2271-6424

Éditeur

Société Française Shakespeare

\section{Référence électronique}

Christy Desmet, «Shakespeare's Scattered Leaves: Mutilated Books, Unbound Pages, and the Circulation of the First Folio ", Actes des congrès de la Société française Shakespeare [En ligne], 37 | 2019, mis en ligne le 07 mars 2019, consulté le 30 avril 2019. URL : http:// journals.openedition.org/shakespeare/4785; DOI : 10.4000/shakespeare.4785

Ce document a été généré automatiquement le 30 avril 2019. 


\section{Shakespeare's Scattered Leaves: Mutilated Books, Unbound Pages, and the Circulation of the First Folio}

\section{Christy Desmet}

When Shakespeare is unbound, is that a good thing or a bad thing? The poster for the 2018 French Shakespeare Society meeting suggests humorously that unbinding the bard is a very good thing (figure 1). Part superhero, part monster, Shakespeare defiantly breaks the chains of the codex book that confines him, his broad grin and furrowed brows telling us all we need to do about the pleasures of destruction and escape from the page's bondage. 


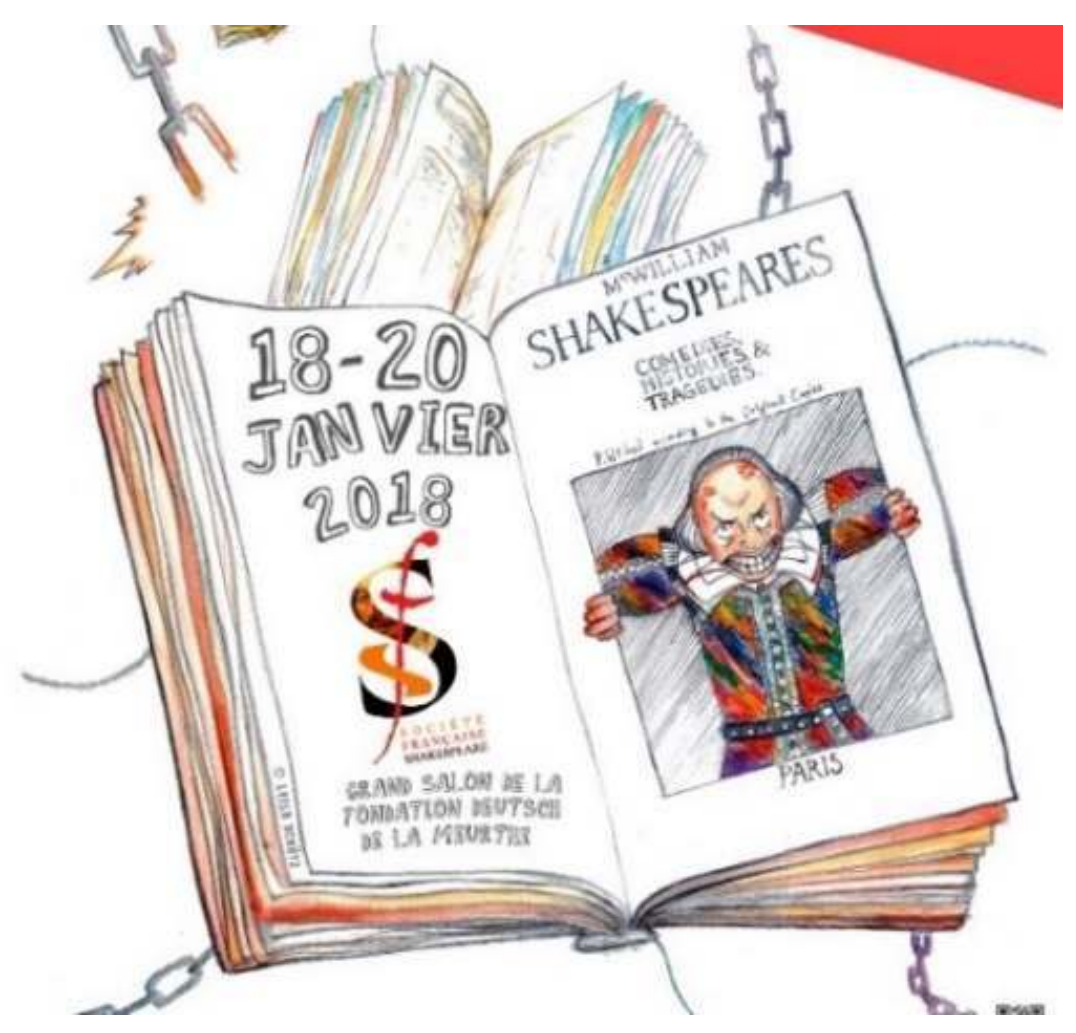

Figure 1. Logo for SFS 2018

More frequently in our post-print era, the end of the book is figured as a tragedy. The book's demise demands elegy; it presages cultural degeneration, even apocalypse. As early as 1992, Robert Coover mourned the passing of printed books, their end paradoxically signaled by a misleading abundance: "The very proliferation of books and other print-based media, so prevalent in this forest-harvesting, paper-wasting age, is held to be a sign of its feverish moribundity, the last futile gasp of a once vital form before it

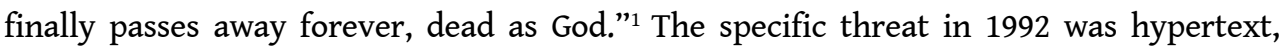
although hypertext's dismantling of the page's integrity through metonymic linkages did not survive the passing of Web 1.0. In 1998, Ian Donaldson would write, in a hopeful vein, "Like the death of the author, the death of the book has been greatly exaggerated." Nonetheless, he offers copious examples of the indignities to which books (and by extension, their authors, even when long dead) are subjected. Take, for example, Byron's ironic discovery that leaves from Samuel Richardson's Pamela were being used to wrap a gypsy's bacon in Tunbridge Wells. ${ }^{3}$ Donaldson highlights as well the book's inherent fragility-a wish for the book to outlast brass and stone that evolves in tandem with anxiety about its vulnerability to dissolution. Notable for this sentiment is Ben Jonson's dedicatory poem to Shakespeare's First Folio:

Thou art a Moniment, without a tombe,

And art alive still, while thy Booke doth live,

And we have wits to read, and praise to give. ${ }^{4}$

This essay argues that contemporary narratives surrounding the circulation and consumption of William Shakespeare's First Folio of 1623 figure the cultural fate of that text in elegiac terms of mutilation and dissolution, but that the celebratory tale of "Shakespeare unbound" emerges in our discourse about the bard as a counter-narrative, 
sustained by the First Folio's increased circulation, in both material and virtual terms, during the twenty-first century.

\section{Mutilated Books and Decaying Pages}

4 From a historical perspective, discourse about books and their history often rests on the metaphor of the book as a mutilated body. As far back as Riddle 26 from The Exeter Book, we find the construction of a bible described in terms of corporeal torture. The personified book narrates first the indignities to which its vellum leaves are subjected in the preparation of a writing surface:

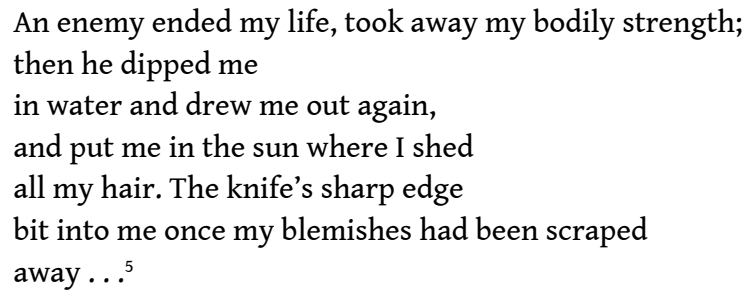

5 As the bible's individual leaves are bound together, the codex book is again put to the rack: "A man bound me, / He stretched skin over me and adorned me / with gold." Within this Christological context, the bodily pains of preparing the bible's vellum leaves ends with the bound book's apotheosis. But this is not always the case. In Riddle 47, we encounter the bookworm who "swallows" the substance of its host and "gorges" on the book's "fine phrases." Here there is no redemption, for the destroying worm does not benefit from the book's destruction; he is "not a whit wiser" for consuming its words.7

Books can meet their demise by physical abuse, but sometimes they simply dissolve into their constituent elements. Today's paper books endure a mechanized form of wholesale mutilation when they are recycled. As Gill Partington and Adam Smyth describe from their visit to a book pulping plant, the volumes are shredded, crushed, and reshaped into new objects. ${ }^{8}$ In accidental book destruction, water is often a culprit. In 2016-2017, the American Bookbinders Museum launched an exhibition called "'Books and Mud: The Drowned Libraries of Florence," commemorating the 1966 Arno River floods that devastated Florence's museums and libraries, when "Medieval and Renaissance-era cultural treasures stored in library and museum cellars steeped for days in water, mud, and sewage." The internet also remains stocked with images of offices and libraries containing water-damaged books from the aftermath of Hurricane Katrina in 2005, when the New Orleans levees were breached. Finally, Kate Flint opens her essay "The Aesthetics of Book Destruction" with a meditation on James Griffioen's photographs of the Detroit Public Schools Book Depository-destroyed by fire in 1987, ruined further by the water used to quench that blaze, then locked up and left to rot: "These volumes are the victims of neglect. The Depository's interiors have a horrible beauty to them, ravaged by fires, exposed to the elements, so that mushrooms grow in the damp ashes of charred and rotted workbooks. ${ }^{10}$ Water is nature's weapon against the printed word, the agent of a slow and unspectacular death. 


\section{Scattered Leaves}

7 A third, less widespread metaphor for the book's material metamorphosis is that of separate leaves or pages scattered by the wind. A look at Google Image or Pinterest will reveal any number of fanciful images of trees adorned with books in their branches, trees made from books, leaves made from cut-up pages of books, and air-borne seeds wafting from books whose pages are fanned open. The conceit acquires literary capital from Nathaniel Hawthorne's The Scarlet Letter, where in "The Custome-House"'s opening sentences, the narrator muses that "the truth seems to be, however, that, when he casts his leaves forth upon the wind, the author addresses, not the many who will fling aside his volume, or never take it up, but the few who will understand him, better than most of his schoolmates or lifemates." ${ }^{11}$ A particularly beautiful literalization of the trope can be found in Nicola Dale's installation Sequel, which consists of a twelve-year-old oak tree felled by the artist's friend, whose leaves are stripped and replaced by artificial leaves "made from the pages of unwanted reference books from charity shops and library sales" (figure 2). ${ }^{12}$ Dale's project is about recycling, cutting up books already slated for destruction in order to recreate them in new artistic forms. Sequel dramatizes the circulation of books and leaves in the material world.

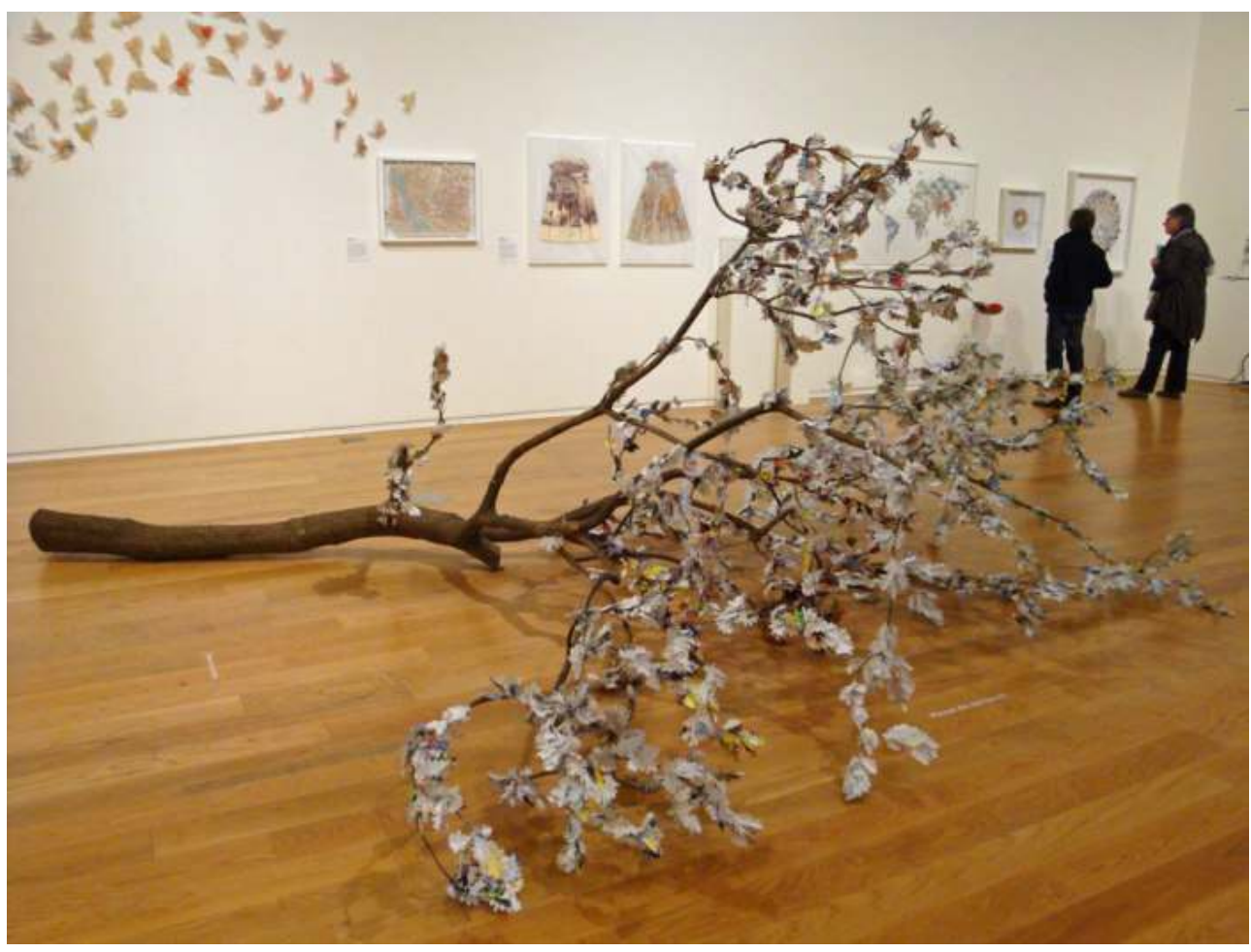

Figure 2. Nicola Dale, Sequel, from the Exhibition The Cut, Manchester Art Gallery, photo from dianajhale,5 January 2013, https://dianajhale.wordpress.com/2013/01/05/paper-landscapes-andmusic/\#jp-carousel-1800

The trope of the book unbound, with pages as scattered leaves, informs as well the contemporary U.S. cult text, Mark Danielewski's House of Leaves. The novel's principal narrative is a gothic tale in which a family takes up residence in a haunted house, whose interior proves to be larger than its exterior. The story turns dark as children disappear into the walls, people die, and a vicious animal seeks to claw through the walls. This story 
is complicated and often confused by the novel's copious paratexts, which range from complex footnotes to multiple appendices and an index so monstrously complete as to be unusable.

Abetted by this information overload, which feeds but also frustrates traditional literary criticism, House of Leaves offers itself to the reader as a material object for aesthetic appreciation. One page features inserts of mirrored sentences, as if the apprentice printer had accidentally printed his page in reverse or the bookbinder had made an error. Another, which appears at the beginning of the chapter "What Some Have Thought," opens with a paragraph in which asterisks substitute for the printed word, denying the access to hidden thoughts that its title has promised. At times, the impossibility of interpretation becomes an overt theme. In another example, we find on the verso side of a page from House of Leaves a slanted list of sayings in different languages, and on the recto, a fairly normal page of type over which is printed, in the style of nineteenthcentury letters that sought to save space by cross-writing, the reiterated phrase "Forgive me" (figures 3 and 4). This text was written, as it turns out when you consult the appropriate appendix, by the schizophrenic and incarcerated mother of House of Leaves's fictional editor, Johnny Truant, before she hangs herself. To understand the relevance of the dark proverbs and snatches of communication on the verso ide to one of the novel's tangled plots-to make sense of the words as information-the reader must penetrate the carefully wrought surface of the book and range further afield in the novel's paratexts.

The proverbs are unfamiliar: for instance "Love's love in her blackest season" or the phrase "Dell'oro, del oro, delore." This last phrase has attracted attention on the plentiful discussion boards dedicated to the novel. For instance, one writer says, "dell'oro, del oro, deloro-(Italian) of the gold, (Spanish) of the gold, the other word has no meaning." ${ }^{13}$ elise paypaert replies, "I am commenting on the Deloro bit. I am a native French speaker, and the first thought I had when I saw the word Deloro was the French word, douloureux, which means painful, sad, or sorrowful. I am not sure if this has any connection, who knows!" Danieleski, or perhaps the editor Truant, or perhaps the mother, gives us an enigma that violates a basic rule of proverbs: that they sound sensible and resist interpretation, but in the end allow "translation." The final word in the triad, deloro, which makes no sense to a wide variety of readers, ensures that the proverb is simply ungrammatical, relying on a nonsense word, a bad grammatical declension, or at best, a semantic false friend (deloro, douloureux). Like the recto page, where the familiar format of a letter degenerates into cross-hatched scribbles, this collection of proverbs invites aesthetic appreciation and intense intellectual scrutiny, but in the end prevents understanding. 


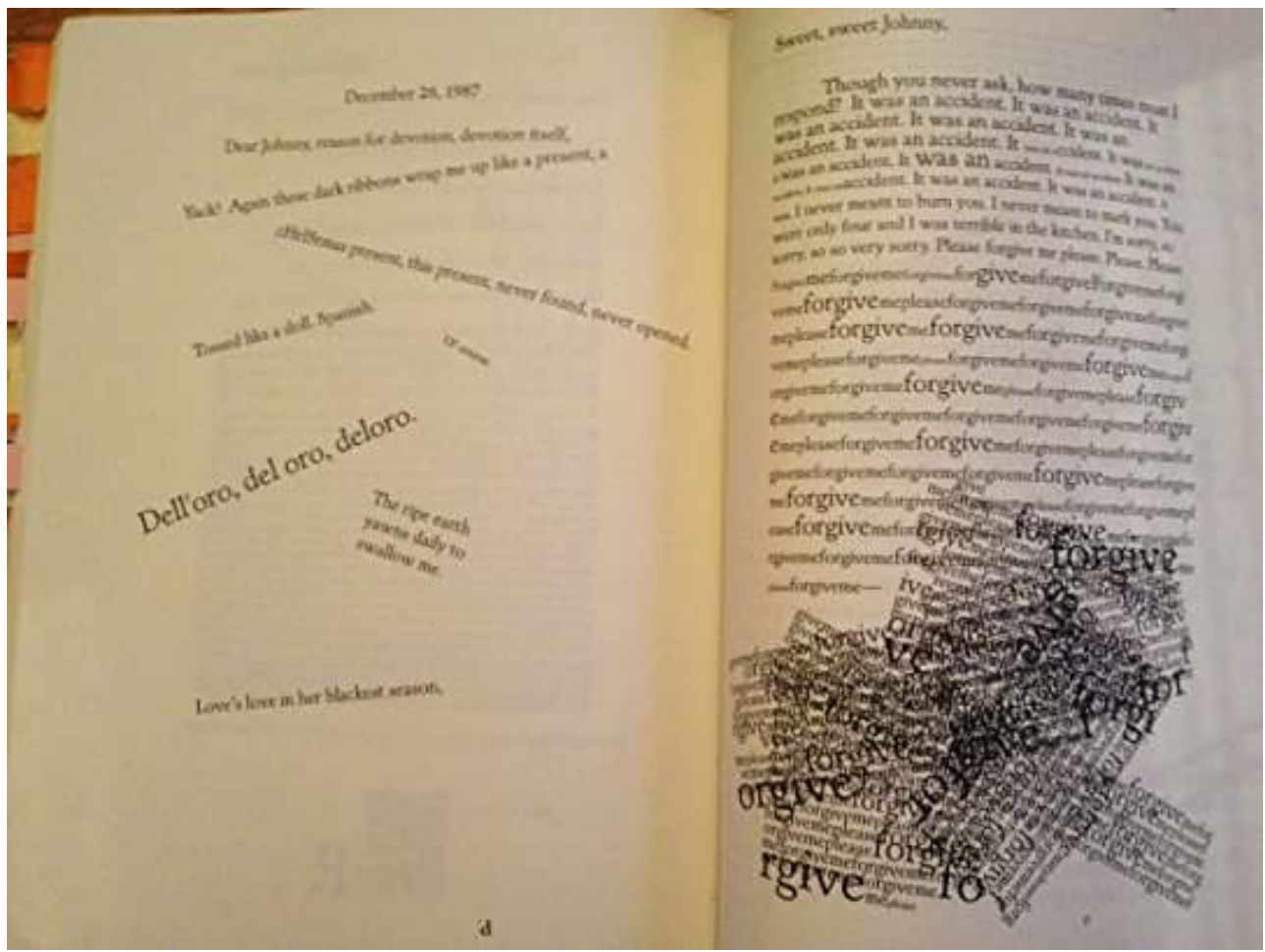

Figure 3. Proverbial Sayings in Mark Danielewski, House of Leaves (Verso Page), http:// www.knowledgelost.org/literature/house-of-leaves-an-art-piece/

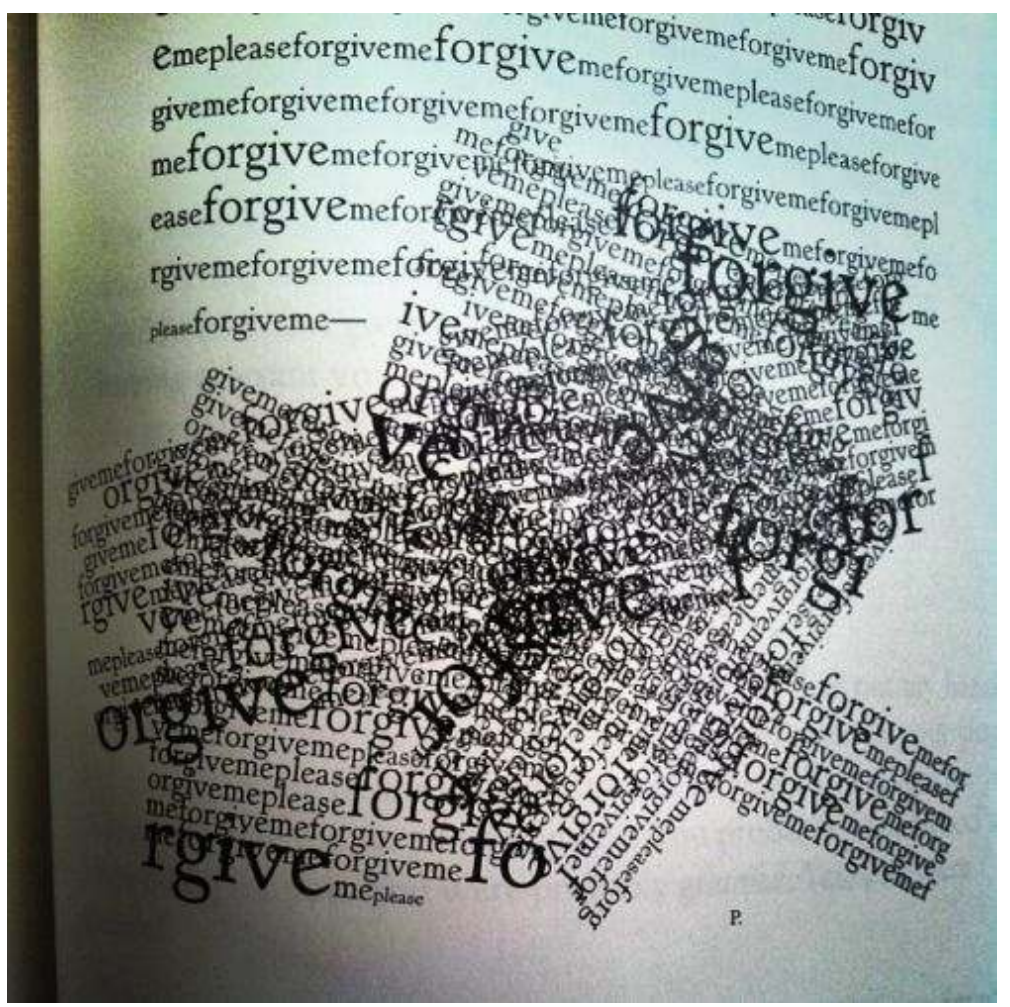

Figure 4. Letter with "Forgive Me" Cross-written in House of Leaves (Recto Page)

11 This kind of textual play will be familiar to readers of Laurence Sterne's Tristram Shandy, but Danielewski's novel makes typographical experiment the dominant mode of book 
creation and consumption. N. Katherine Hayles describes the reader's experience of House of Leaves through Richard A. Lanham's model of "at" versus "through" vision: the "complementary perspectives of looking through a page (when we are immersed in a fictional world and so are scarcely conscious of the page as a material object) and looking at the page, when innovative typography and other interventions encourage us to focus on the page's physical properties. ${ }^{14}$ In House of Leaves, however, the dominance of images and fanciful typography means that the material page often overwhelms information. In another illustration, the menacing house of unfathomable proportions is itself reduced to a textual palimpsest of words upon words, rendered un-readable by heavy over-writing and marred by another "black hole" with bleeding ink to create a narrative lacuna that mimics the holes into which the house's inhabitant are sucked (figure 5). As a novel built on words, House of Leaves proves to be as fragile as Dale's textual tree in Sequel. In this case, it's all allegory, no story.

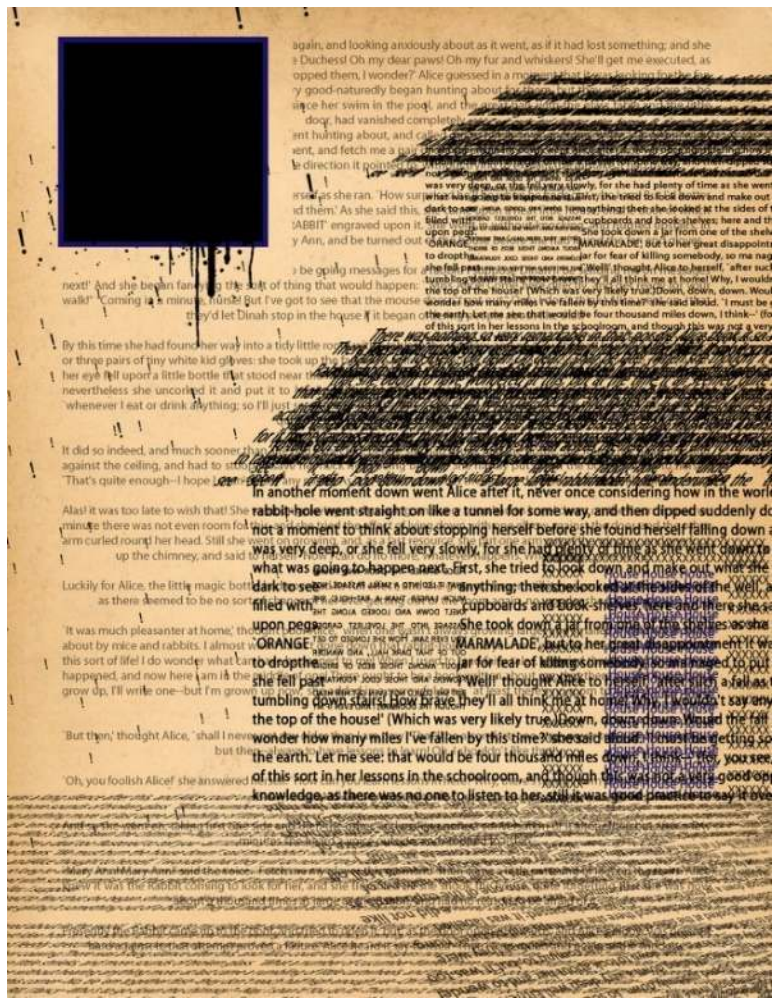

\section{Figure 5. The House as Page or Book Leaf Made from Printed Words}

While the palimpsest is a repeated trope in House of Leaves, the image of the novel as a tree makes a last-minute appearance on the novel's final page, appearing, unexpectedly, after the index. As Mark B. N. Hansen describes it, "the page bears the inscription 'Yggdrasil' in the form of a $\mathrm{T}$ followed by four lines of text and a fifth line containing a single, large-font, bold $\mathrm{O}$. A reference to the giant tree supporting the universe in Norse mythology, the page startles in its apparent randomness, reinforcing the well-nigh cosmological closure effected by the novel it culminates, yet shedding no new light on just what should be made of it." ${ }^{15}$ This mythological tree, as the novel's promised, if terminally delayed, telos, is contradicted by the novel from its very beginning, The inside cover to the 2016 paperback edition-proclaims that the novel first circulated as both material and virtual versions of the unbound text: 

Prospero's books glide, page by page, across the screen, shimmering and vibrating with life, with John Gielgud's voiceover detailing their qualities and quirks. The companion volume to Greenaway's film, also titled Prospero's Books, catalogues the books and gives insight into their spectacular qualities. To give just one example, the Book of Motion, unveiled rather late in the film, vibrates precariously on its lectern as Prospero, attended by spirits, regresses from the library. According to the "catalogue description" in both book and film, The Book of Motion is "covered in tough blue leather and, because it is always bursting open of its own volition, it is bound around with two leather straps buckled tightly at the seams. At night, it drums against the bookcase and has to be held down with a brass weight." 20

Years ago, when House of Leaves was first being passed around, it was nothing more than a badly bundled heap of paper, parts of which would occasionally surface on the Internet. No one could have anticipated the small but devoted following this terrifying story would soon command ... Now, for the first time, this astonishing novel is made available in book form, complete with the original colored words, vertical footnotes, and newly added second and third appendices. ${ }^{16}$

"scattered leaves," circulated in manuscript or on the internet, which were then recuperated and bound together as a printed codex with meticulous production values. While to my knowledge no trace of the original textual fragments persists in cyberspace to corroborate this statement, Danielewski did create an online forum "to coincide with the release of the novel" that had postings in nine languages, although mostly in English and French. ${ }^{17}$ (Thomas Davidson claimed in 2014 that the forum was still active, and when I registered on 23 May 2018, I noted at least one new post for that day and several from the past month; as we saw in the discussion of the word "dolere," above, other readers' forums continue to form.) In this way, according to Davidson, "the space of House of Leaves and its many participants is characterized by a network of geographically dispersed, yet interconnected nodes across which agency is distributed..$^{18}$ The unbound book whose leaves are cast to the wind morphs into the network more characteristic of the computer age. We see another version of this dialectic between networks and books in Peter Greenaway's film Prospero's Books.

\section{Shakespeare in Circulation: Prospero's Books}

Peter Greenaway's film adaptation of Shakespeare's is, among many other things, a reflection on the use and abuse of books. As Partington and Smyth note in the Introduction to their edited volume on "book destruction," "Books are two-faced; on the one hand they are totems: carriers of culture, values, beliefs. But on the other hand, they are quotidian objects: material and ephemeral things, subject to decay and physical obsolescence like any other." ${ }^{19}$ The volumes that star in Prospero's Books are equally twofaced, at once objects of wonder, sources of practical knowledge, and part of the domestic landscape.

The twenty-four books introduced to viewers in the course of the film are first and foremost totems-art objects like House of Leaves, or even supernatural art objects. But as Partington and Smyth would say, these books are also quotidian objects. We find them scattered haphazardly around the bathhouse pool, their unprotected leaves riffling 
in the wind (figure 6). Books can also be put to more traditional uses on the island. Prospero tutors Miranda from The Book of Nature, but when she encounters Ferdinand for the first time, she can be spied handing off to a cherub what proves, upon closer inspection, to be The Book of Love. Engravings of mythological figures in close embrace suggest that this smaller volume (rather incomplete in its content, according to the voiceover), is at once an extra-curricular guide for Prospero's innocent daughter and a book still waiting to be completed and corrected by the island's chaste couple.

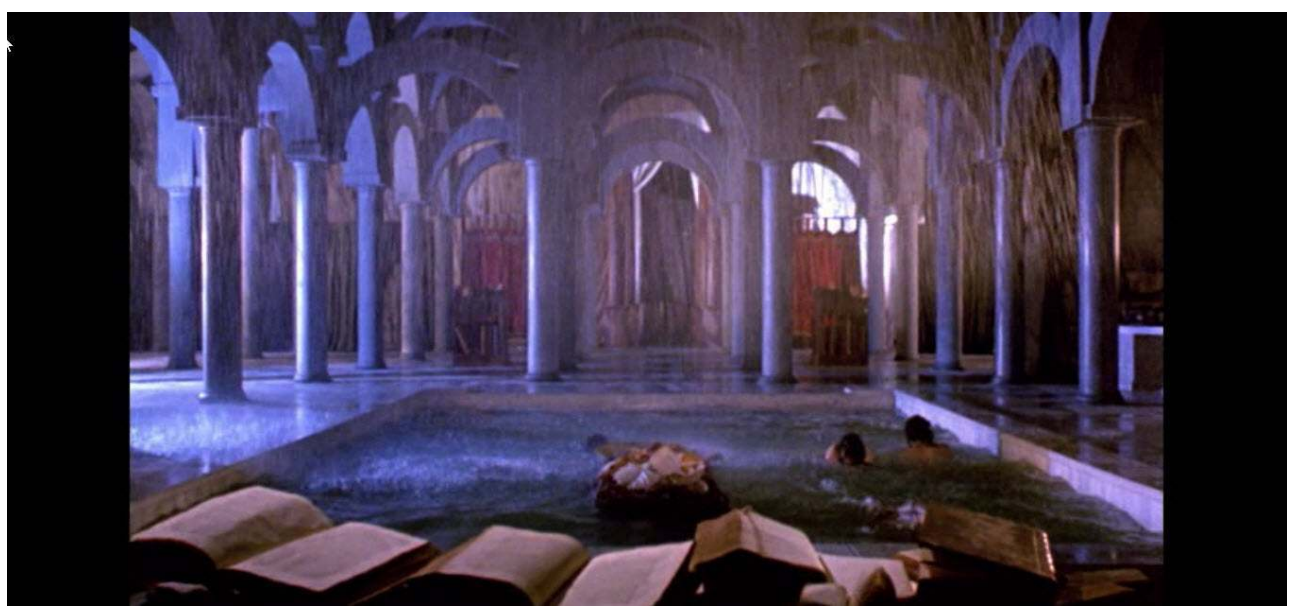

Figure 6. Books Scattered Casually around the Bathhouse Pool in Prospero's Books; Screen Grab $\underline{\text { DVD }}$

Prospero's Books, following Shakespeare's gesture in this direction, also offers a primer in book destruction, figured in the familiar terms of mutilation and dissolution. Antonio's usurpation of Prospero's rule involves burning his library. Caliban, as in Shakespeare, rages against the book knowledge of his youth. In the film, he nevertheless has possession of at least one volume, whose pages he rips out, stabs, and defiles with his own bodily waste (figure 7). Books also suffer from both normal and extraordinary wear and tear. The "scratched and rubbed" crimson leather cover from The Book of Traveller's Tales testifies to children's love for the book, while the "battered and brunt" green tin cover of An Atlas Belonging to Orpheus bears the marks of hellfire and Cerberus's teeth. The Book of Water, despite being waterproof, is still damaged and has "lost its color by much contact with water." ${ }^{21}$ Finally, the ceremonial destruction of Prospero's library is achieved by not a book burning, but a book drowning, as Prospero and Ariel hurl volume after volume into the water surrounding Caliban's lair.

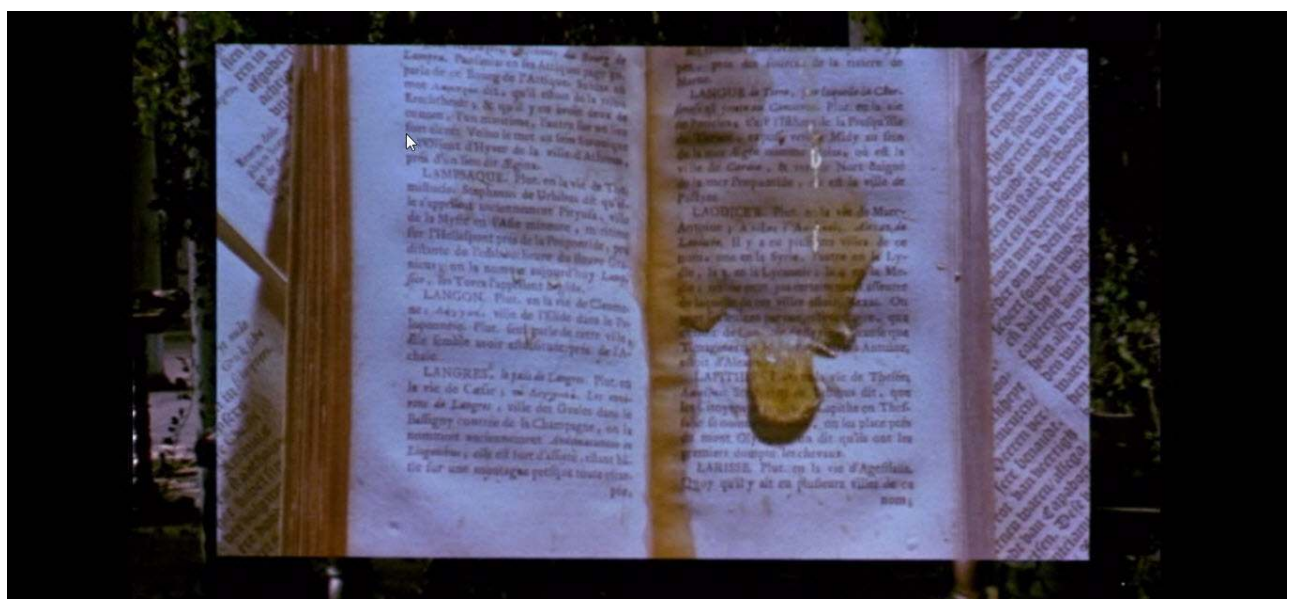


Prospero's books invite "at" and "through" vision in a cinematic version of the wordimage dialectic found in House of Leaves. Just as Danielewski's novel tempted us toward the house's conceptual black holes with a trick of vision (see figure 5), in a trompe l'oeil sequence at the opening of Prospero's Books, we pass through the pages of The Book of Water to glimpse the floundering Neapolitan ship (figure 8). ${ }^{22}$

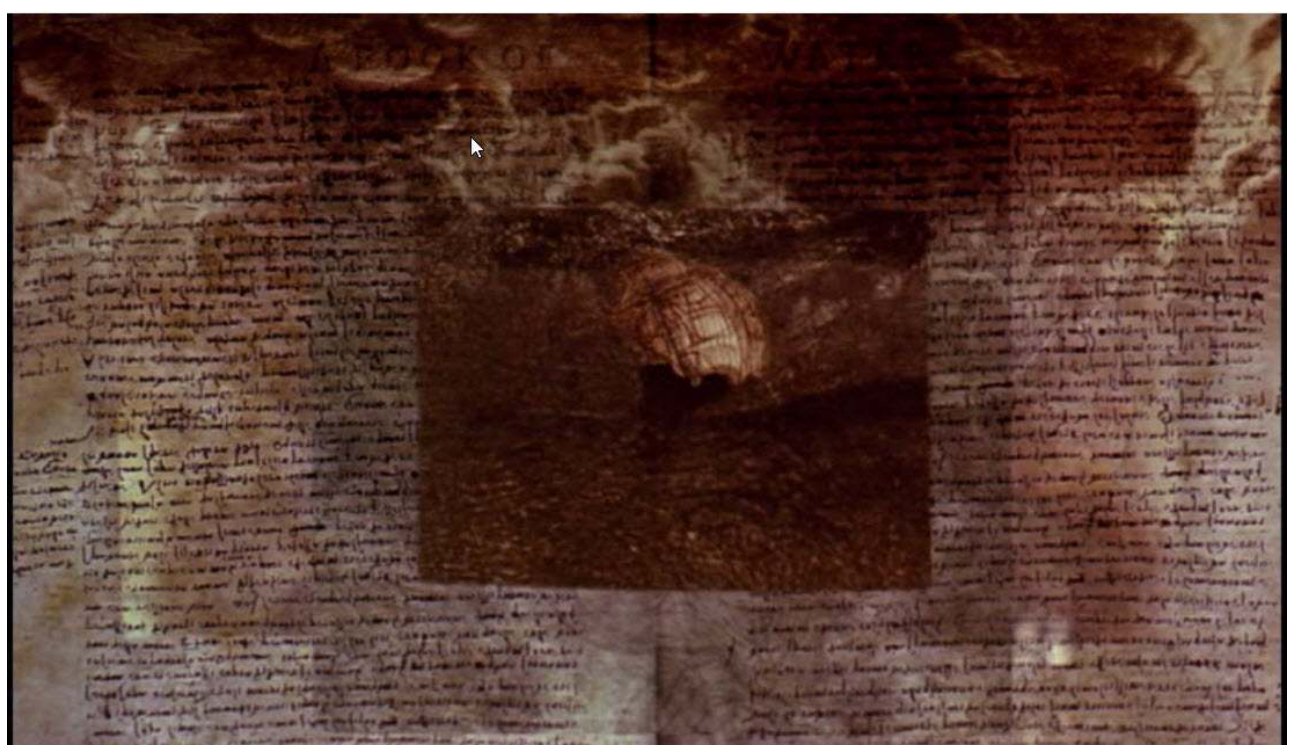

Figure 8. The Book of Water "Opens up" a Window on the Neapolitan Ship, Screen Grab DVD

While bodily damage and dissolution are the film's dominant tropes for the end of books, Prospero's Books also figures the cycle of a book's creation and decay in terms of its binding and unbinding. While we often see Prospero writing on parchment in an elegant italic hand to create his manuscript volumes, Greenaway's film also celebrates the binding of books as a mechanized process more readily associated with age of print. At the film's beginning, spirit ballerinas form an assembly line, handing off volumes to one another, as unbound book leaves circulate wildly through the air-fanned by the earnest puffing of Botticellian spirits, presumably to coalesce in the artistically bound volumes of Prospero's library (figure 9). Even when library is empty, the pages continue to circulate restlessly through the air (figure 10). While scattered leaves of books convey in this instance the energy of book creation, wind-blown book leaves also blow across the desolate landscape Caliban inhabits as just more form of human detritus, further evidence of the printed word's evanescence (figure 11). 


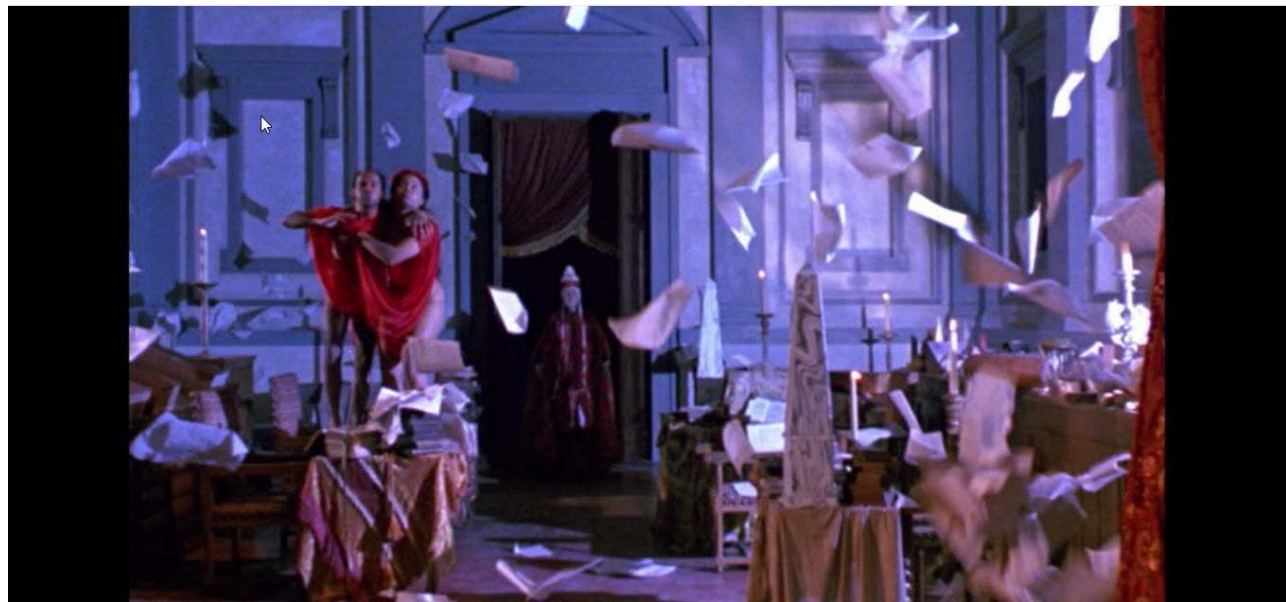

Figure 9. Spirits Fanning the Air as Books Leaves Circulate in Prospero's Library, Screen Grab DVD

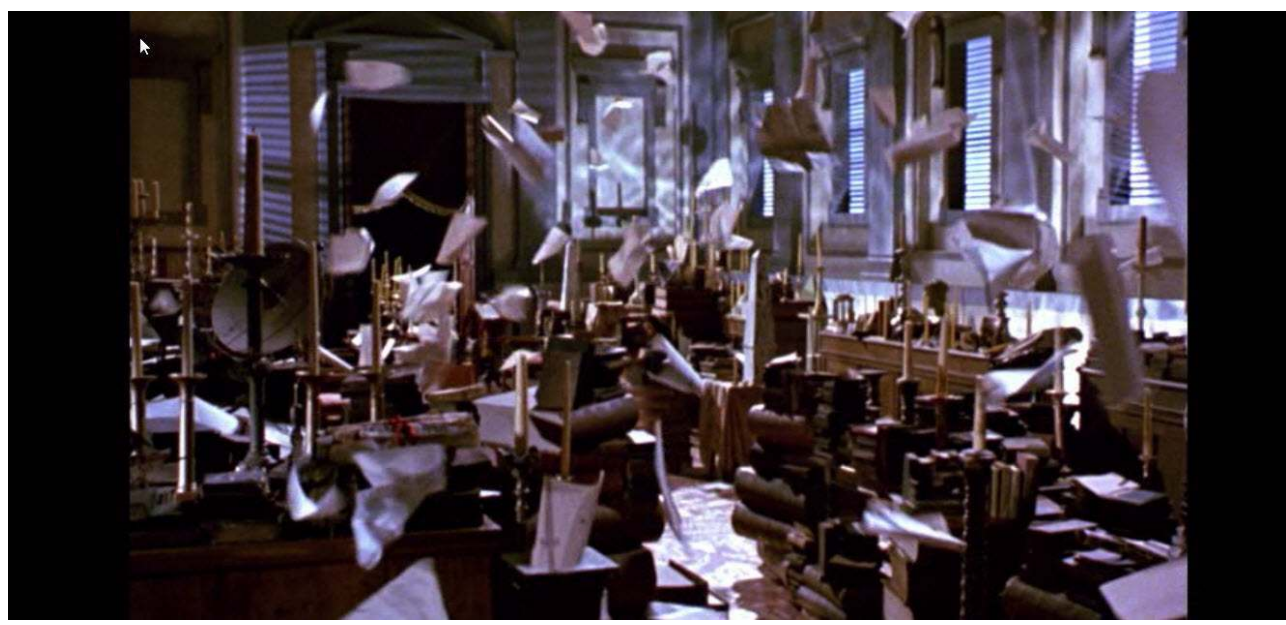

Figure 10. Papers Circulating through Prospero's Empty Library, Screen Grab DVD

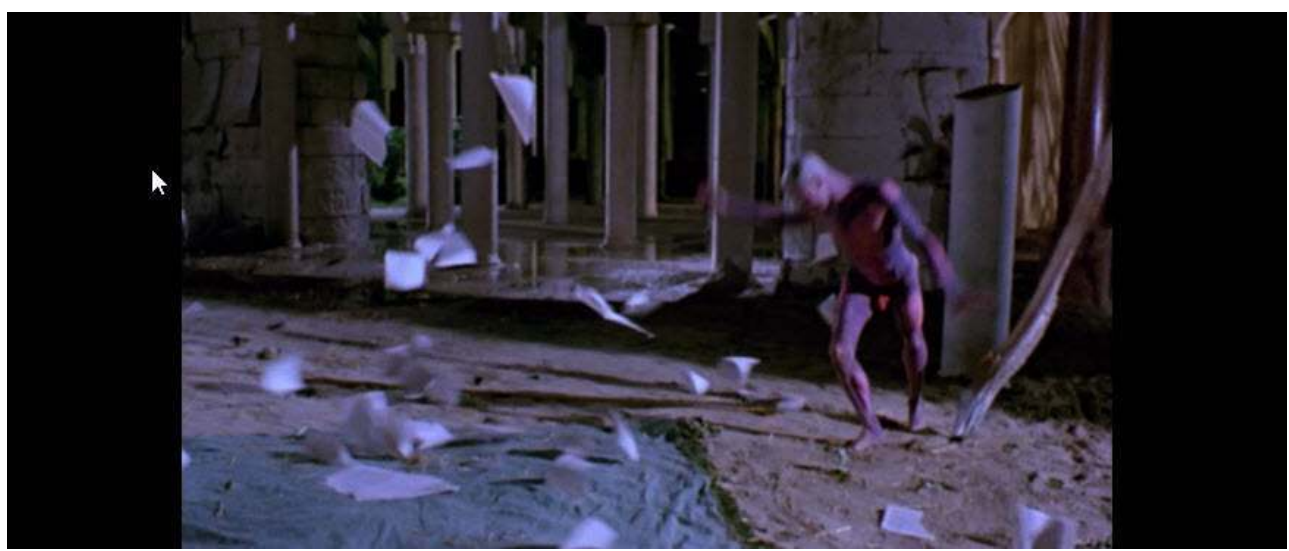

Figure 11. Pages of Ripped-up Books Swirl across Caliban's Desert Habitat, Screen Grab DVD 


\section{Perfecting Shakespeare's Book}

21 The least prepossessing among Prospero's books in the Peter Greenaway film is the last, coyly entitled Thirty-Six Plays:

This is a thick, printed volume of plays dated 1623. All thirty-six plays are there, save one-the first. Nineteen pages are left blank for its inclusion. It is called The Tempest. The folio collection in modestly bound in dull green linen with cardboard covers and the author's initials are embossed in gold on the cover-W. S. ${ }^{23}$

years, been a saga of perfecting - both beautifying and completing-the damaged, vagrant copies of that book. In The Shakespeare Thefts, Eric Rasmussen tells the tale of the hunt for all extant copies of the Folio, which are brought together finally in the Descriptive Catalogue of Rasmussen and Anthony James West. ${ }^{24}$ Rasmussen's accompanying detective story records not only the scholars' mission but also the damage and indignities suffered in the past by these copies of the First Folio. One may (or may not) have been deliberately burned in a Spanish library. ${ }^{25}$ The Mesei University copy in Tokyo, which once belonged to Thomas Killigrew, follower of Charles I, sports a bullet hole that penetrates all the way through to the first page of Titus Andronicus. ${ }^{26}$ In one of the most sensational scandals, where the First Folio ostensibly found in Cuba turned out to have been stolen by Raymond Scott from the Durham University Library, physical damage to the codex was assimilated to the national body from whom the volume was untimely ripped. Stephen C. Massey meticulously examined the folio that Scott had brought into the Folger Shakespeare Library for verification. Immediately, Massey "could see that the binding was missing and that the volume had been scoured of all identifying marks by someone who knew what he or she was doing." ${ }^{27}$ Testifying at Scott's trial, then Head Librarian of the Folger Shakespeare Library Richard Kuhta characterized this subterfuge as a crime, stating that the book was "a cultural legacy that has been damaged, brutalized, and mutilated." The presiding judge agreed; passing sentence on Scott, he "condemned the damage to the First Folio as 'cultural vandalisation' of a 'quintessentially English treasure."'28

While as a book, Shakespeare's First Folio suffers mutilation and decay, it is also a tree denuded of leaves. As Rasmussen and also Emma Smith point out, almost all extant copies of the First Folio are incomplete. ${ }^{29}$ Early owners filled their lacunae often being filled with spare leaves from incomplete copies, the meticulous nineteenth-century pen-and-ink facsimiles of James Harris (figure 14), ${ }^{30}$ or one of the later, or photographic facsimiles from the twentieth century. Finally, there are the hyper-perfected extra-illustrated copies, where the Folio pages are adorned with illustrated scenes from the plays (figure 13).

Actes des congrès de la Société française Shakespeare, 37 | 2019 

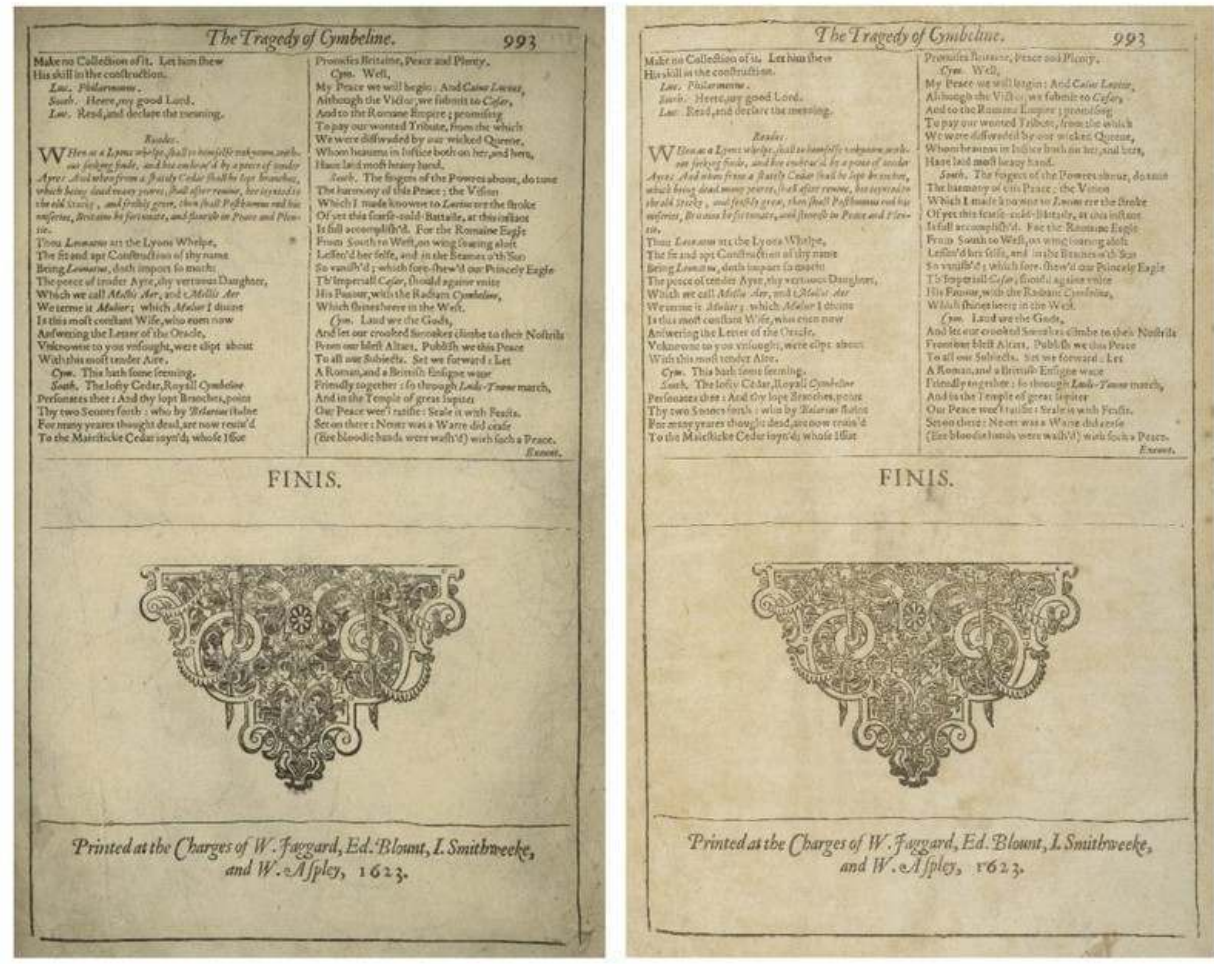

Figure 12. James Harris pen-and-ink facsimile of Cymbeline's final page at left in comparison to an original leaf. Folger copy 23. https://collation.folger.edu/2013/05/pen-facsimiles-of-early-print/

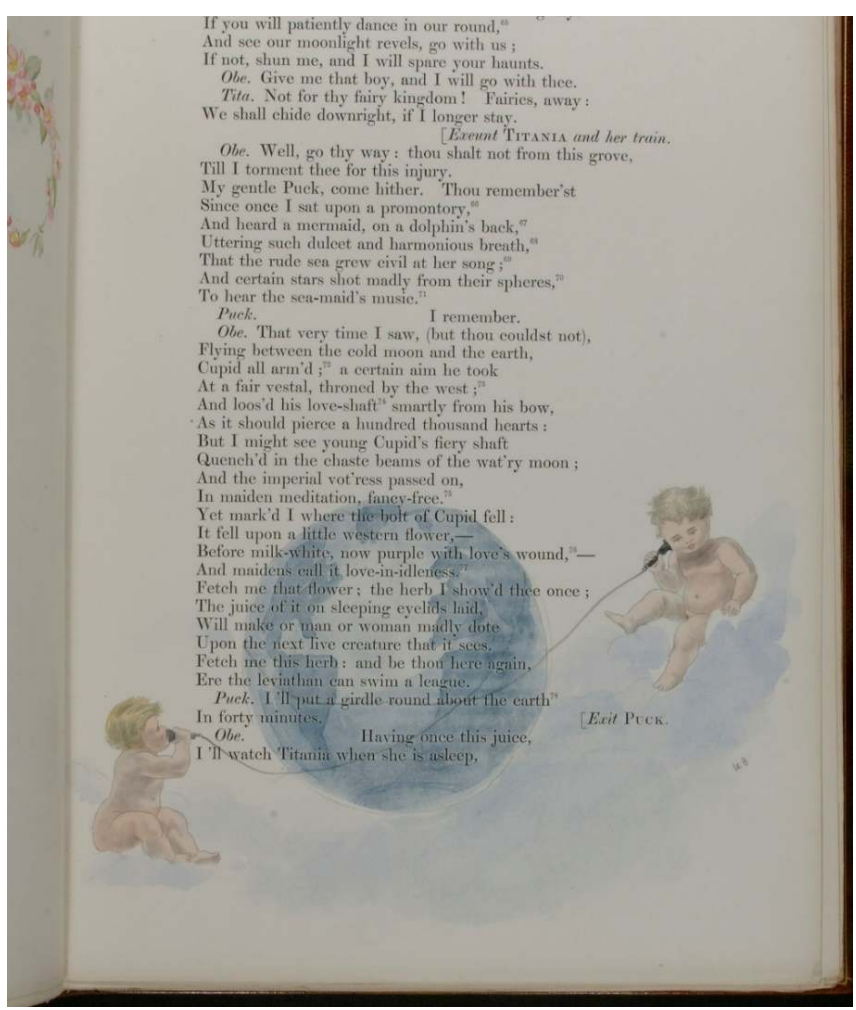


Figure 13. Puck girdles the earth via Telephone in the Huntington Library's Adlard Shakespeare. By permission of the Huntington Library. https://extra.shu.ac.uk/em/s/si-21/Ferrell_illustration03.jpg

Smith and Rasmussen both contextualize the project of "perfecting" the Folio within the book's economic fortunes. Shakespeare's First Folio is not a particularly rare book, and so does not command high prices on account of its scarcity, its artistic merit, or its condition -simply on the basis of its author's celebrity. In fact, until George Steevens remarked on the high prices commanded by copies of the Folio in the eighteenth century, the Folio had lost its use-value; hence, the need for a second, third, and fourth Folio. ${ }^{31}$ Even the Bodleian, which received the deposit copy of Shakespeare's First Folio from the printer, bound originally by William Wildgoose of Oxford, de-accessioned the First Folio and replaced it with a copy of the Third Folio, as being more useful or up-to-date..$^{32}$ The cover of the Bodleian First Folio is worn, the endpapers ripped and patched, and in the upper right corner of the cover is visible the tear where the book was ripped from its chain when it was discarded (figure 14). As described in Rasmussen and West's complete catalogue of First Folios, there is serious damage on the lower right of the first page of The Tempest (figure 15). ${ }^{33}$

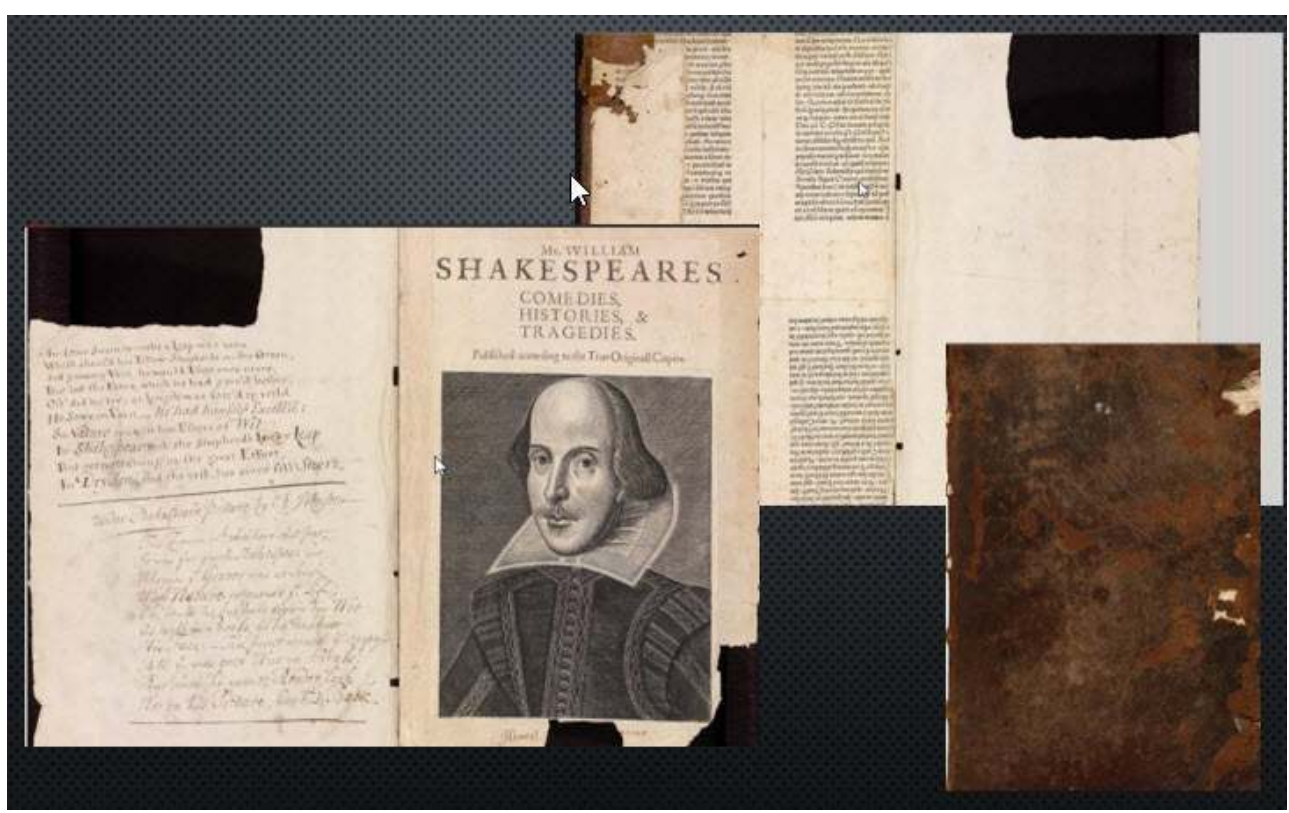


Figure 14. Bodleian First Folio, with Ripped Leaves, Marginalia, and (at top right) Damage to the Book's Cover where It Was Ripped from Its Library Chain, http://firstfolio.bodleian.ox.ac.uk, composite by Christy Desmet

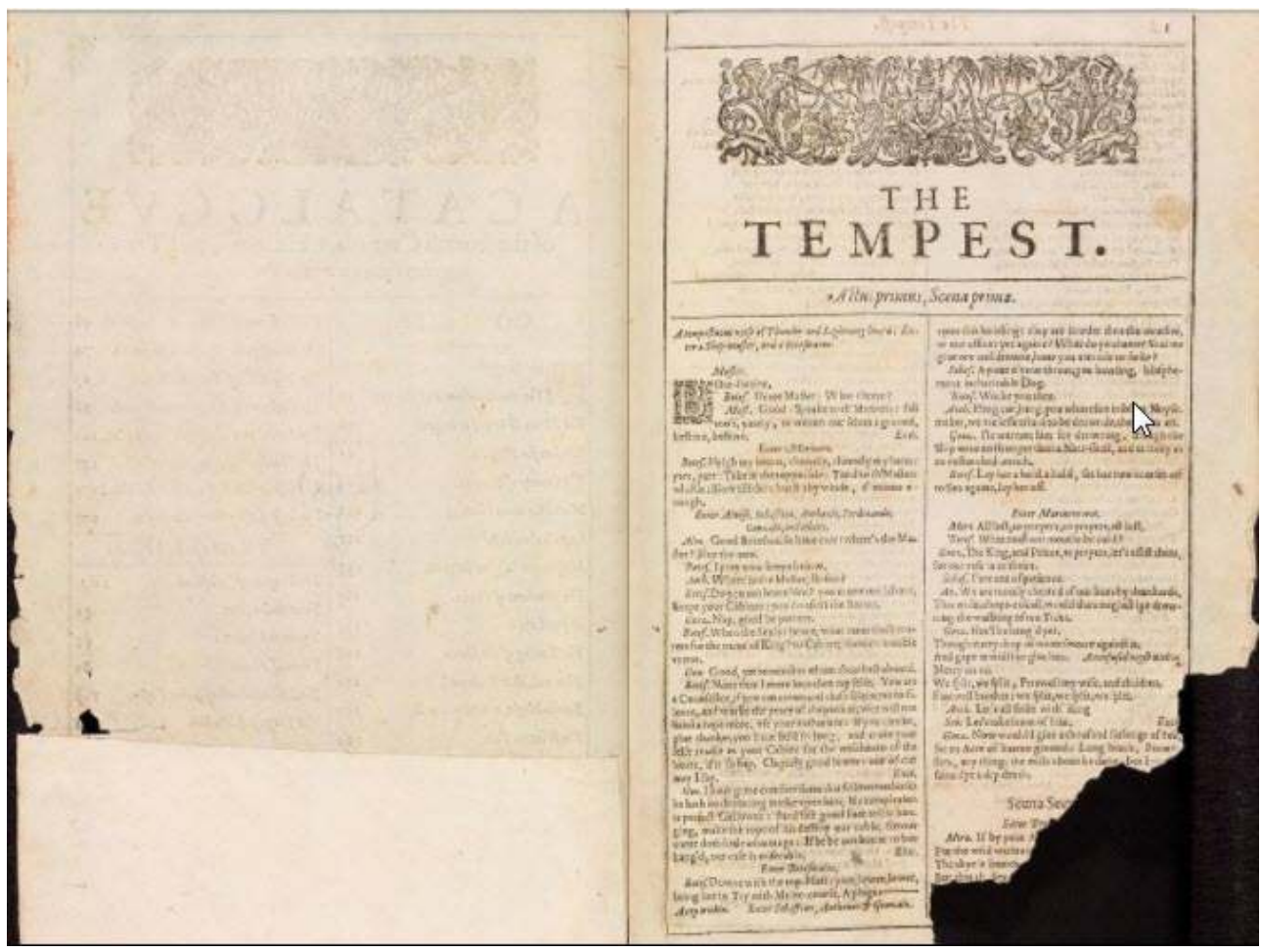

Figure 15. First Page of The Tempest, Bodleian First Folio, Bodleian Arch. G c.7, http:// firstfolio.bodleian.ox.ac.uk

\section{Disseminating the First Folio in the Twenty-first Century}

Thus far, we have two meta-narratives in counterpoint with one another: a story of loss, mutilation, and dispersal against the tale of Shakespeare's Folios perfected and finally brought back together by scholarship, money, and justice. The twenty-first century offers two new spins on the First Folio's story. The first is the dissemination of the material text through the Folger Shakespeare Library's 2016 First Folio tour. The second is the unbinding and circulation of Shakespeare's "scattered leaves" via the Internet. In many ways, the First Folio tour represented the apotheosis of the book as object or sacred relic. There were many rituals surrounding the selection of the site, carefully regulated procedures for its transport (a Folger representative accompanied each copy to its destination) and its display (the books were all opened to Hamlet's "To be or not to be" soliloquy). ${ }^{34}$ At the same time, however, the tour offered a tour de force literalization of the bard's long reach. Although not exactly "scattered," the Folger's Folios circulated widely throughout the United States during the years 2016.

Before and after the Shakespeare 2016 celebration, rare book libraries have also taken up the task of distributing their rare books, Shakespeare's First Folio among them, in digital form via the Internet. Smith notes that the St.-Omer Shakespeare, discovered in plain 
sight in a French library and probably the most dramatic excerpt in Rasmussen's travelogue, was digitized almost immediately after its discovery. ${ }^{35}$ This manner of distribution paradoxically increases those books' cultural capital with the act of widespread, free dissemination.

In their current state, digital First Folios are being made available to the public in multiple formats for different users. Both the Bodleian First Folio and Folger First Folio no. 68 can be downloaded as single JPEG images (another form of separated leaves; see figure 16), and both can be animated and read by clicking the "Play" button, so that the Folio's pages turn automatically in a manner reminiscent of the books lining the edge of Prospero's pool in the Greenaway film. ${ }^{36}$ Like the modern-edition Folger Digital Texts, the Bodleian First Folio site also allows users to download a PDF of the digital edition that accompanies the scanned page images and the XML (Extensible Markup Language) text that underlies the digital text. Text marked-up for digital display is "cut-up" in yet another way, separated into its constituent elements and labelled in preparation for user access (figure 17). In the digital age, Shakespeare's first Folio is "unbound" and rebundled for varied purposes and people.

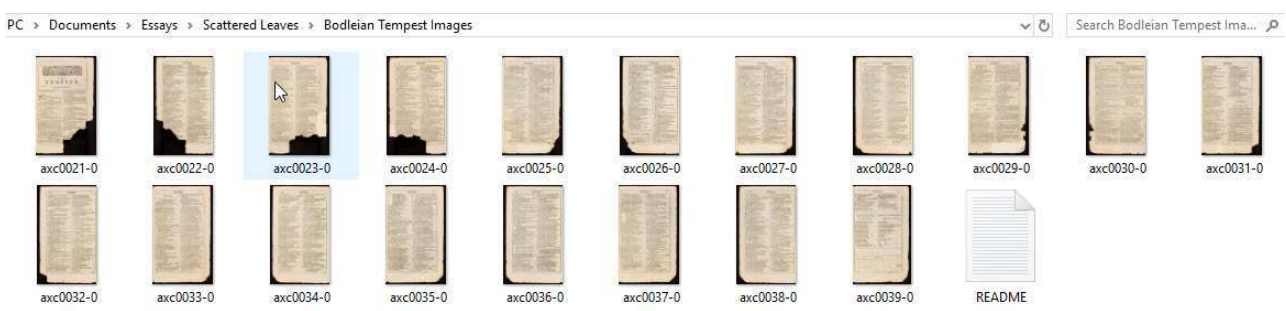

Figure 16. High Resolution Images from the Bodleian First Folio, Ready for Downloading, http:// firstfolio.bodleian.ox.ac.uk/downloads.html\#pdfs

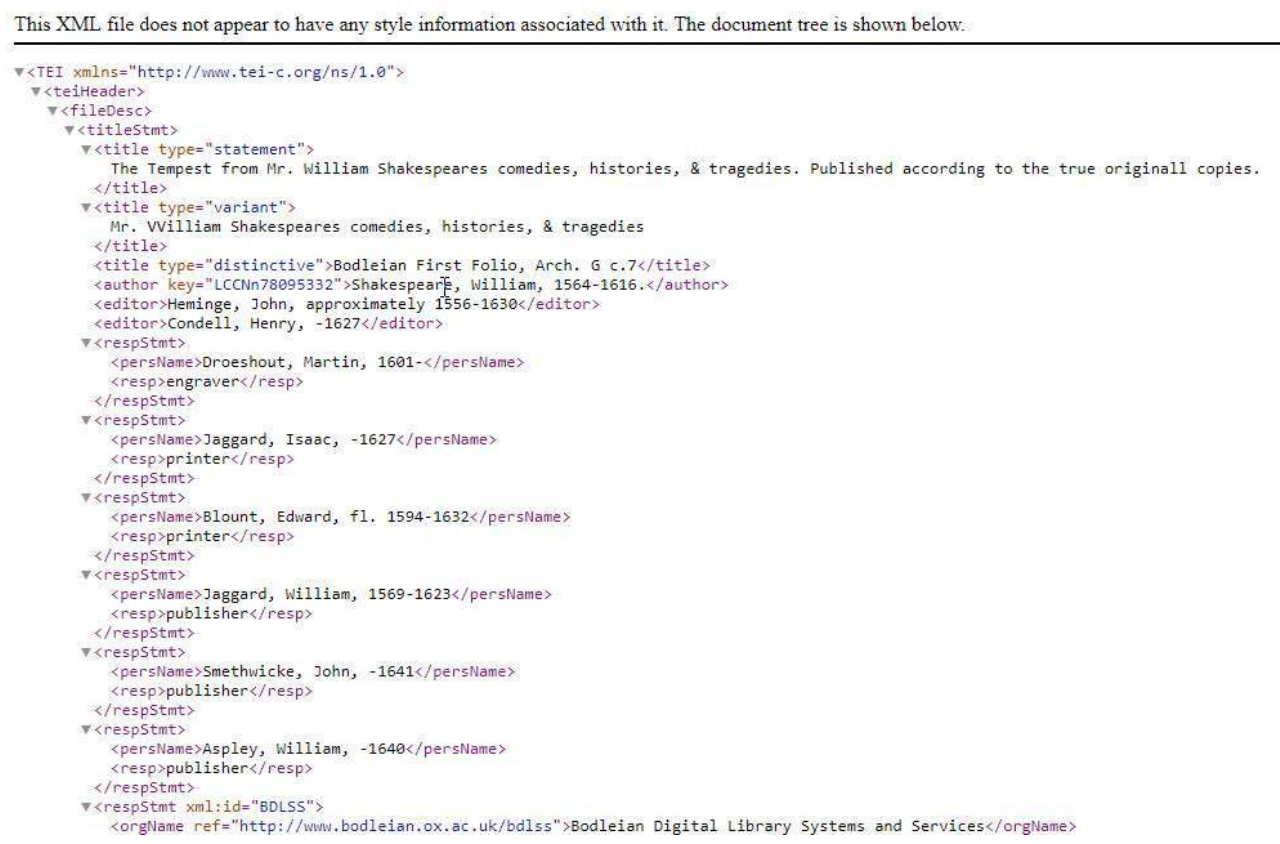

Figure 17. Bodleian Library First Folio, XML Text of the First Page of The Tempest

The use-value of these digitized copies, however, remains under debate. In 2016, Sarah Werner noted that 

greater number of people than earlier technologies. It is now possible for teachers to easily task students with looking at the earliest printed texts of the plays, for theatre practitioners to consult the plays without the intervention of modern editors, and for everyone from the general public to advanced scholars to examine the First Folio text for their own purposes. ${ }^{37}$

31 Werner suggested further that electronic copies of the Folios could make accessible to ordinary users such previously arcane evidence as stop-press corrections, a task that Werner models in a posting on her personal blog. ${ }^{38}$ But Werner also pointed to limitations that hamper scholarly use of these assets: for instance, most do not allow readers to search by through-line numbers (TLN), so that browsing and stumbling upon information is the default search mode. More generally, the dismantling of the first Folio into its constituent pages creates logistical problems for users. In many ways, the constraints of using digitized Folios are similar to those that plague previous attempts to enable comparisons between different Shakespeare texts in printed form. For example, Michael Warren's ambitious and astronomically expensive Complete King Lear from 1989 seeks

to demonstrate the distinctiveness and uniqueness of the three early printed texts of King Lear: to heighten awareness not just of their similarities but also their dissimilarities; to provoke and facilitate continuing contemplation of the problem of the single designation King Lear for a nexus of complex issues. It is a resource book that allows immediate contact with the diverse elements of King Lear. ${ }^{39}$

This multi-part scholarly kit consists of a bound book offering a general introduction and parallel texts in facsimile of the First Quarto and First Folio texts, with lines of facsimile text of corrected pages recorded in a separate column. The remainder of the package consists of loose pages reproducing uncorrected and invariant/corrected states of the different texts. In this way, the reader can play human Hinman Collator by placing uncorrected and corrected pages literally next to one another for comparison. The photographs of The Complete King Lear reproduced here show not only the superior production values of this facsimile compilation, but also its pitfalls; managing this information is complex, and it is always possible to shuffle the pages from three separate packets out of order (figure 18). Whether in paper or digitized format, the scattered leaves of Shakespeare's multiple texts are a challenge to re-assemble in a useful manner.
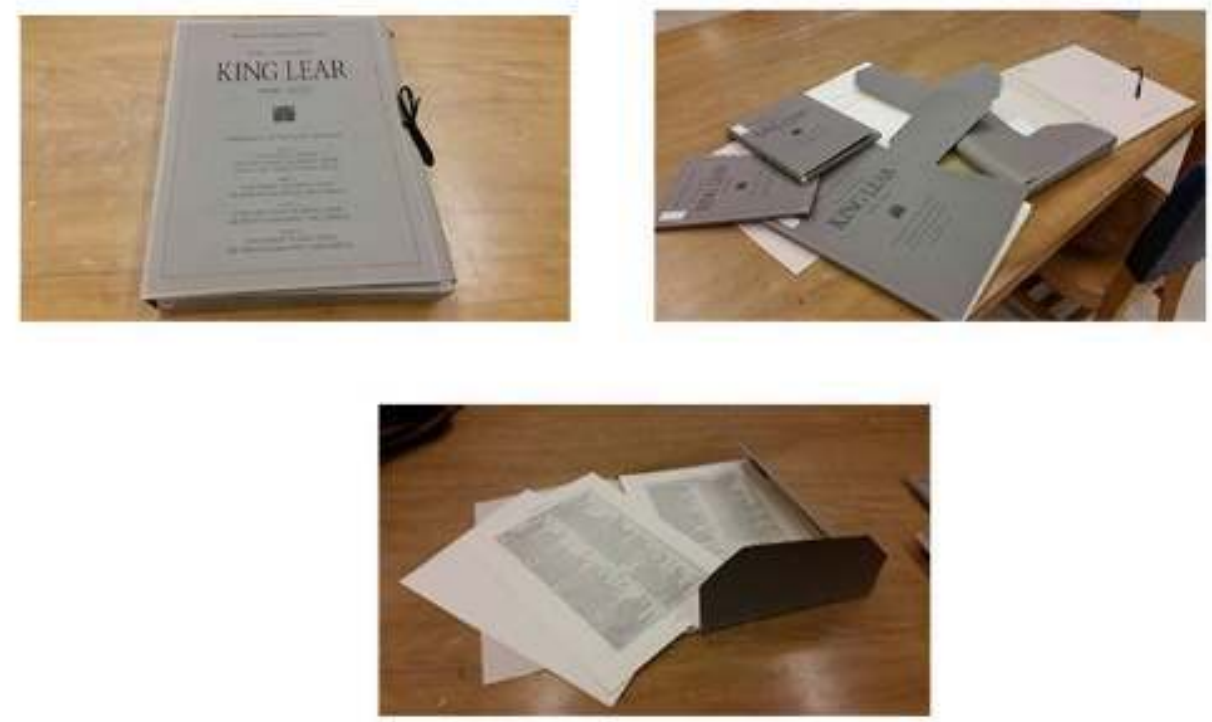

Actes des congrès de la Société française Shakespeare, 37| 2019 
Figure 18. Michael Warren's Complete King Lear (1989), Photos by Christy Desmet availability of explanatory supplements to focus readers' visual attention and comprehension of information. Dale's Sequel does not make complete sense unless the viewer knows that the beautiful artificial tree is constructed from discarded reference books; and certainly, the secrets of Greenaway's magical books remain hidden without John Gielgud's explanatory voiceover or the companion volume, Prospero's Books. As Werner says in her 2016 essay, most digitized First Folios available at the time of writing lack the kind of paratext that can help amateurs make sense of the scattered pages they find. That paratext may be supplied by Rasmussen and West's Shakespeare's First Folios: A Descriptive Catalogue. ${ }^{40}$ Although by no means democratic in its pricing ( $\$ 437$ U.S. just for the Kindle version), this user-friendly volume is really a delight to look through. Some of the excitement of the chase that Rasmussen chronicles in The Shakespeare Thefts also manages to come through here. The account of each Folio begins with the most interesting information (history, provenance, and owners) and leaves the matter only a professional bibliographer could love (press variants and watermarks) until the end of each entry. With the print catalogue as supplement, the scattered digitized leaves of Shakespeare's First Folio can be used as well as admired, returning us to that moment, in Prospero's Books, when The Book of Love provided useful information for a woman who has met only two men in her life and now must improvise her a first meeting with her future husband.

The dialectic between looking at a facsimile surface as an aesthetic object and looking through to its content, which the digitized First Folios, House of Leaves, and Prospero's Books share, relies not only on the affordances of new media (desktop publishing and digitization), but on an important constraint or holdover from the printed codex. For all three projects, the page remains the relevant unit for consumption of and scholarship about these books. In the discourse surrounding facsimile texts, as Bonnie Mak argues, "The adoption of a model of supersession"-where manuscript yields to manuscript codex to printed book and then inevitably to the digital edition-is a mirage. ${ }^{41}$ In whatever medium, we continue to approach books as collections of separate pages or leaves.

The current state of digital Shakespeare First Folios may eventually allow a wider group to users to become more cognizant of the technologies that shape the page, the unit by which these books are currently transmitted to us. In the meantime, the examples of Prospero's Books and House of Leaves demonstrate what we can do with the scattered leaves of Digital Shakespeare First Folios: concentrate on the page rather than the book and oscillate between what "at" vision-looking with artistic finesse at the surface of a pageand "through" vision-reading for the message on a facsimile page. This might accomplish, or at least approximate, the democratizing goal attempted by Michael Warren's Complete King Lear: making available to a wider variety of Shakespeare users the tools to unpack the secrets of Shakespeare's Big Book.

\section{Coda}

At the end of Greenaway's film, Prospero drowns all of his books, including the incomplete First Folio and his manuscript of The Tempest. After the book drowning,

Actes des congrès de la Société française Shakespeare, 37 | 2019 
Caliban slips in to rescue the two latter volumes, taking them down beneath the water's surface to his hidden lair. Many readers see this gesture as a triumph for Shakespeare and for the book, but placed within the context of Rasmussen's tale of the Shakespeare Thefts, the triumph is at best ambivalent. Like the original Folios, this one disappears from view and will certainly suffer damage from its aquatic journey, to resurface who knows when and in what condition, given Caliban's penchant for book destruction. Peter Donaldson, however, notes that the First Folio Tempest does somehow find its way into print, as its text, in shimmering gold letters, scrolls up the screen over the final union of Miranda and Ferdinand (figure 19):

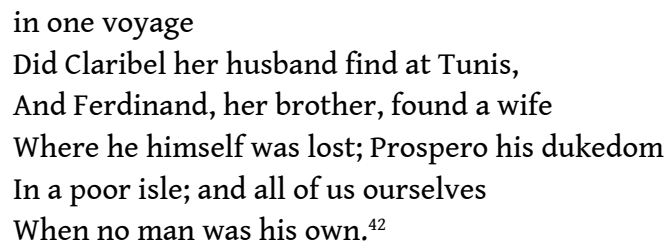

Donaldson argues that with this gesture, Prospero "is installed as a permanent, authorizing presence" to "remystify the book" as originary discourse. ${ }^{43}$ His conclusion is just, but captures only partially the conclusion to The Tempest's story, for Gonzalo has proposed that this statement be "set . . . down / With gold on lasting pillars." ${ }^{44}$ We can now imagine at least three versions of these words-those on the pillars, in the First Folio itself, and on the screen-that survive the drowning of Prospero's manuscript Tempest or, depending on one's interpretation, its theft and sequestration by Caliban. As noted above, the First Folio was never a rare book; it became valuable because of its author's celebrity status. Thus, the unbound pages of Shakespeare's First Folio, replicated and scattered across the internet, paradoxically gain rather than lose cultural capital through their plenitude. In digitized form, shakespeare's scattered leaves secure their author's status by circulating endlessly in libraries and classrooms, downloaded to computers and tablets, and passing through the hands of professionals and amateurs alike.

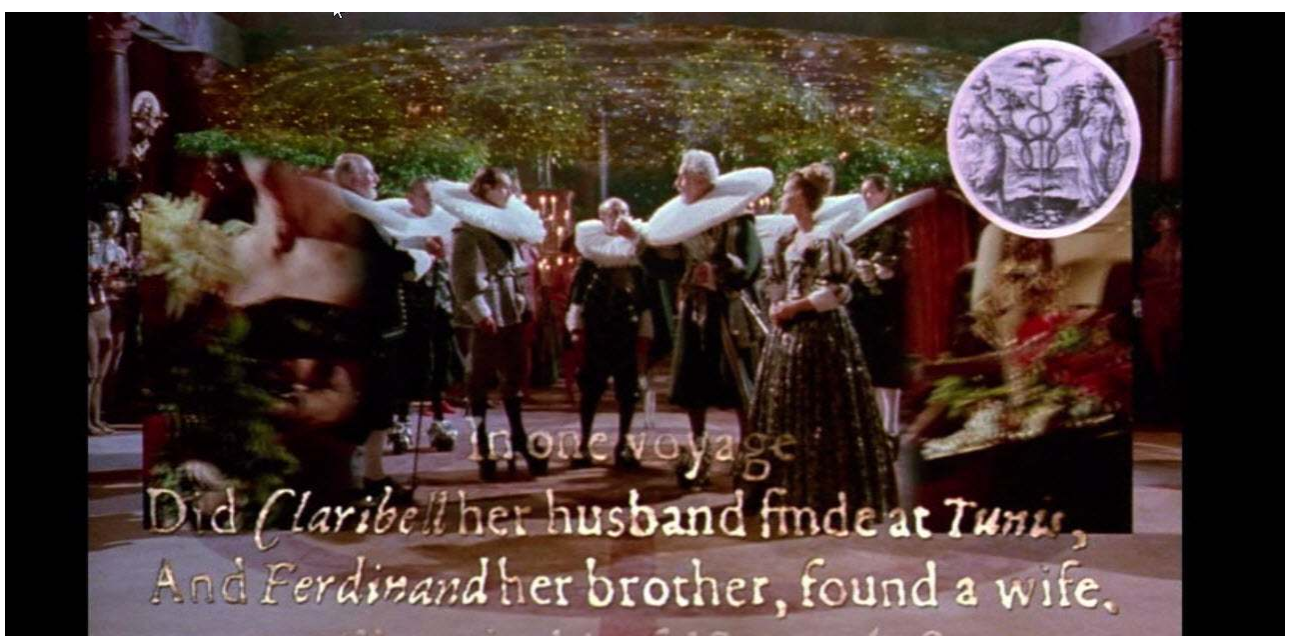


Figure 19. Lines from the Printed First Folio Tempest (5.1.249-251) Scroll across the Screen at end of Prospero's Books; Screen Grab, DVD

\section{NOTES}

1. Robert Coover, "The End of Books," New York Times, 21 June 1992, https:// archive.nytimes.com/www.nytimes.com/books/98/09/27/specials/coover-end.html?

pagewanted=all

2. Ian Donaldson, "The Destruction of the Book," Book History, 1, 1998, 1-10, p. 2.

3. Ibid., p. 3.

4. Folger Shakespeare Library First Folio, no. 68, A4r, https://www.folger.edu/the-shakespearefirst-folio-folger-copy-no-68\#page/Fourth+page+of+preliminaries/mode/2up

5. The Exeter Book Riddles, trans. Kevin Crossley-Holland, rev. ed., London, Enitharmon Press, 2008, Kindle Book, loc. 400.

6. Ibid.

7. Ibid., loc. 592.

8. Gill Partington and Adam Smyth, Introduction to Book Destruction from the Medieval to the Contemporary, London, Palgrave Macmillan, 2014, 1-14, pp. 1-3.

9. "50th Anniversary of Florence Flood Inspires Exhibition at the American Bookbinders Museum," American Bookbinders Museum, https://bookbindersmuseum.org/events/books-andmud-the-drowned-libraries-of-florence/

10. Kate Flynt, "The Aesthetics of Book Destruction," Partington and Adam Smyth, op. cit., 175-189, p. 176.

11. Nathaniel Hawthorne, The Scarlet Letter: A Novel, New York, Easton Press, 1975, p. 3.

12. Adam Smyth, Gill Partington, and Nicola Dale, "Kindle: Recycling and the Future of the Book: An Interview with Nicola Dale," in Partington and Smyth, op. cit., 190-217, p. 194.

13. shins pearl, "Language Translations," and elise pypaert , "Reply," "Appendix II. E-The Three Attic Whalestoe Institute Letters," House of Leaves, The Book Club, Livejournal, 28 July 2008, https://bookclub33.livejournal.com/4026.html

14. N. Katherine Hayles, "Saving the Subject: Remediation in House of Leaves," American Literature, 74, no. 4, 2002, 779-806, p. 794; referring to Richard A. Lanham, The Economics of Attention: Style and Substance in the Age of Information, Chicago, University of Chicago Press, 2006.

15. Mark Z. Danielewski, House of Leaves, second edition, New York, Pantheon, 2000, p. 709; Mark B. N. Hansen, "The Digital Topography of Mark Z. Danielewski's House of Leaves," Contemporary Literature, 45, no. 4, 2004, 597-636, p. 598.

16. Danielewski, op. cit., inside book cover to paperback edition.

17. Thomas Davidson, "The Spatio-Temporal Dimensions of Mark Z. Danielewski's House of Leaves: 'Real Virtuality' and the 'Ontological Indifference' of the Information Age," Word and Image: A Journal of a Literary Studies and Linguistics, 4, no. 1, 2014, 70-82, p. 80.

18. Ibid., p. 73.

19. Partington and Smyth, op. cit., p. 4.

20. Peter Greenaway, Prospero's Books: A Film of Shakespeare's The Tempest, by Peter Greenaway, New York, Four Walls, Eight Windows, 1991, p. 24.

21. Ibid., p. 20, 17. 
22. Among the many of examinations of the dialectic between word and image Prospero's Books are analyses by Mariacristina Cavecchi, "Peter Greenaway's Prospero's Books: A Tempest between Word and Image," Literature/Film Quarterly, 25, no. 2 (1997), 83-89; Lia M. Hotchkiss, "The Incorporation of Word as Image in Peter Greenaway's Prospero's Books," The Reel Shakespeare: Alternative Cinema and Theory, Madison, NJ, Fairleigh Dickinson University Press, 2002, 95-107; and James Tweedie, “Caliban's Books: The Hybrid Text in Peter Greenaway's Prospero's Books," Cinema Journal, 40, no. 1, 2000, 104-126.

23. Ibid., 23. The cardboard covers and cheap green linen seem unhistorical. Emma Smith reports that dark calf on board was the most popular option (The Making of Shakespeare's First Folio, Oxford, Bodleian Library, 2015), p. 158.

24. Eric Rasmussen, The Shakespeare Thefts: In Search of the First Folios, New York, St. Martin's, 2011; Eric Rasmussen and Anthony James West, The Shakespeare First Folios: A Descriptive Catalogue, New York, Palgrave, 2012.

25. Rasmussen, op. cit., p. 7 ff.

26. Rasmussen, op. cit., p. 77.

27. Rasmussen, op. cit., p. 29.

28. Rasmussen, op. cit., p. 39, 43.

29. Emma Smith, Shakespeare's First Folio: Four Centuries of an Iconic Book, Oxford, Oxford University Press, 2016, who writes that "most extant Folios are . . . a combination of facsimiles, imported leaves, and original leaves" (p. 34).

30. Rasmussen, op. cit., p. 63.

31. On the economic fortunes of the First Folio, and its increase in value during the eighteenth century, see Smith, Chapter 1, "Owning," The Making of Shakespeare's First Folio, pp. 24-120; and Anthony James West, The Shakespeare First Folio: The History of the Book, Volume 1: An Account of the First Folio Based on its Sales and Prices, 1623-2000, Oxford, Oxford University Press, 2001.

32. Rasmussen, op. cit., p. $72 \mathrm{ff}$.

33. "The Tempest, A1 heavy water damage affects lower outer quadrant of all leaves through C2; affected replaced with printed facsimile. A1v vertical tear from foot affects 2 letters b63, 65. A2v $22 \mathrm{~mm}$ tear a42 affecting 4 letters ..." cited in Rasmussen, op. cit., p. 25.

34. Public relations information about the tour can be found at "First Folio! The Book that Gave Us Shakespeare," https://www.folger.edu/first-folio-tour; further information is included at "How the First Folio Tour Came Together" https:// shakespeareandbeyond.folger.edu/2016/11/22/first-folio-tour-backstory/; you can see the stringent requirements for applications at the American Library Association (ALA) site: https:// apply.ala.org/shakespeare/guidelines

35. Emma Smith, Shakespeare's First Folio, p. 335.

36. "Read the Book," The Bodleian First Folio, http://firstfolio.bodleian.ox.ac.uk/book.html; Folger Digital Texts, http://www.folgerdigitaltexts.org/

37. Sarah Werner, "Digital First Folios," in The Cambridge Companion to Shakespeare's First Folio, ed. Emma Smith, Cambridge, Cambridge University Press, 2016, p. 170.

38. Sarah Werner, "First Folios Online," Wynken de Worde: Books, Early Modern Culture, and Postmodern Readers, 22 April 2013, http://sarahwerner.net/blog/2013/04/first-folios-online/

39. Michael J. Warren, The Complete King Lear, 1608-1623, Berkeley, University of California Press, 1989, p. xiv-v.

40. It is instructive to read this volume in contrast to Peter W. M. Blaney, The First Folio of Shakespeare, Washington, DC, Folger Shakespeare Library, 1991; Charlton Hinman's The First Folio of Shakespeare, New York, Norton, 1996; and Anthony James West's The Shakespeare First Folio: The History of the Book, 2 vols., New York, Oxford, 2001-2005-all of which are impeccable in their scholarly credentials, but accessible only to specialists.

41. Bonnie Mak, How the Page Matters, Toronto, University of Toronto Press, 2011, p. 9. 
42. The Tempest, 5.1.249-254; Folger Shakespeare Library. The Tempest, from Folger Digital Texts, ed. Barbara Mowat, Paul Werstine, Michael Poston, and Rebecca Niles, Folger Shakespeare Library, 25 May 2018, www.folgerdigitaltexts.org

43. Peter S. Donaldson, "Shakespeare in the Age of Post-Mechanical Reproduction: Sexual and Electronic Magic in Prospero's Books," Shakespeare the Movie: Popularizing the Plays on Film, TV, and Video, ed. Lynda E. Boose and Richard Burt, $1^{\text {st }}$ ed., London and New York, Routledge, 1997, 169-185, p. 175.

44. The Tempest, 5.1.248-249.

\section{RÉSUMÉS}

Le cycle de vie des livres est souvent exprimé à l'aide de tropes pour dire la destruction. Les plus communes sont la métaphore des livres comme corps torturés ou bien comme objets dissous dans l'eau, tandis que celle du livre comme arbre dont les feuilles sont emportées par les vents offre une alternative, un modèle moins négatif. Le présent essai examine chacune de ces tropes afin de montrer que les récits contemporains qui sont faits de la création, de la circulation et de la consommation du Premier Folio de Shakespeare (1623) figurent la destinée culturelle de ce texte dans les termes élégiaques de la mutilation et de la dissolution, alors que ceux qui célèbrent un "Shakespeare désenchaîné" à travers la dispersion des "feuilles" ou des pages du Premier Folio font émerger dans notre discours sur le barde un contre-récit fondé et alimenté par la dissémination toujours plus large du Premier Folio au format papier ou numérisé au cours du vingt-et-unième siècle.

The life cycle of books is often expressed through tropes of destruction. Most common are the metaphor of books as a tortured bodies or objects dissolved by water, but the book as a tree whose leaves are scattered to the winds offers an alternative, and less, negative model. This essay examines each of these tropes to argue that contemporary narratives surrounding the creation, circulation, and consumption of William Shakespeare's First Folio of 1623 figure the cultural fate of that text in elegiac terms of mutilation and dissolution, but that the celebratory tale of "Shakespeare unbound" through the scattering of the First Folio's "leaves" or pages emerges in our discourse about the bard as a counter-narrative, confirmed and sustained by the First Folio's increased dissemination, in both material and digitized form, during the twenty-first century.

\section{INDEX}

Keywords : Bodleian First Folio, Dale Nicola, Danielewski Mark Z., Folger Shakespeare Library, Greenaway Peter, House of Leaves, Prospero's Books, Rasmussen Eric, Sequel, Shakespeare First Folio, Shakespeare Thefts, Shakespeare William

Mots-clés : Dale Nicola, Danielewski Mark Z., Folger Shakespeare Library, Greenaway Peter, House of Leaves, Premier Folio de la Bodleian, Premier Folio de Shakespeare, Prospero's Books, Rasmussen Eric, Sequel, Shakespeare Thefts, Shakespeare William 


\section{AUTEUR}

\section{CHRISTY DESMET}

University of Georgia (USA) 